\title{
Parvovirus-Induced Transient Aplastic Crisis in a Patient With Newly Diagnosed Hereditary Spherocytosis
}

\author{
Nitish Singh Nandu ${ }^{1}$, Husam Hafzah ${ }^{1}$, Charmi Patel ${ }^{2}$ \\ 1. Internal Medicine, Chicago Medical School, Rosalind Franklin University, North Chicago, USA 2. Internal Medicine, \\ Rosalind Franklin University of Medicine and Science, North Chicago, USA
}

Corresponding author: Nitish Singh Nandu, nitishsinghnandu@gmail.com

\begin{abstract}
Parvovirus B19 infections are prevalent in children and commonly present as slapped cheek fever, also known as the fifth disease. They are seen frequently in daycares and professions that require close contact with children. The most common presentation is a rash that is prominent on the cheeks; less common symptoms include painful or swollen joints (polyarthopathy syndrome). The infection is self-limited and resolves within one to two weeks. The virus has an affinity to the red blood cell (RBC) precursors and can rarely cause temporary cessation of the bone marrow's RBC production, leading to aplastic anemia. This is especially of significance in patients predisposed to increased RBC destruction, such as hereditary spherocytosis, sickle cell anemia, and other morphological abnormalities of the RBC. The overlapping arrest of RBC production and excessive destruction leads to a transient aplastic crisis (TAC), leading to severe lifethreatening anemia, requiring blood urgent blood transfusions. There have been many studies reporting the incidence of TAC in patients with sickle cell crisis. Only a few cases have been reported in patients with hereditary spherocytosis.
\end{abstract}

Categories: Internal Medicine, Infectious Disease, Hematology

Keywords: parvovirus, hereditary spherocytosis, aplastic crisis

\section{Introduction}

Human parvovirus is a non-enveloped single-stranded DNA virus from the Parvoviridae family and is the only member known to be pathogenic to humans. The virus is transmitted by respiratory droplets and seen commonly in children. Parvovirus b19 infection is prevalent with seropositivity in up to $60 \%$ by age 30 years. It causes erythema infectiosum in immunocompetent children but can manifest as pure red cell aplasia in the immunocompromised [1]. Parvovirus directly attacks and destroys proerythroblasts by attaching to the blood group P antigen receptor [2]. Transient aplastic crisis (TAC) is a temporary cessation of red cell production by the bone marrow leading to severe anemia, most commonly seen in patients predisposed to increased RBC destruction. Hereditary spherocytosis is a membrane defect of the RBC, which causes the loss

Received 06/24/2020

Review began 06/25/2020 Review ended 06/29/2020 Published 07/03/2020

\section{() Copyright 2020}

Nandu et al. This is an open access article distributed under the terms of the Creative Commons Attribution License CC-BY 4.0., which permits unrestricted use, distribution, and reproduction in any medium, provided the original author and source are credited. of the standard biconcave shape leading to spherical RBC, spherocytes. These RBCs are easily prone to destruction while passing through the capillaries. When TAC occurs in such patients, the destruction of circulating cells, along with the lack of new cell production, leads to severe anemia that can be lifethreatening. There have been many studies reporting the incidence of TAC in patients with sickle cell crisis. Only a handful of cases have been reported in hereditary spherocytosis [2-4]. We report an example of a TAC revealing undiagnosed hereditary spherocytosis in a 23-year-old patient.

\section{Case Presentation}

A 23-year-old male was brought to the emergency room (ER) for evaluation after a syncopal episode. The episode was without involuntary shaking, tongue biting, and bowel or bladder incontinence. He had no similar episodes in the past. He reported no significant past medical history. However, he reported cough, sore throat, subjective fever, and chills one week before the presentation. Family history was significant for hereditary spherocytosis in his mother and younger brother. He had a blood pressure of 117/66 mmHg, a heart rate of $98 / \mathrm{min}$, and a temperature of $98.7^{\circ} \mathrm{F}$. Upon physical exam, he had a bruise on the left side of his face from the fall, and enlarged tonsils with grayish exudates. There was no rash, lymphadenopathy, or hepatosplenomegaly. Labs showed hemoglobin and hematocrit of $5.0 \mathrm{~g} / \mathrm{dL}$ and 13.6\%, respectively. One week prior, they were $11.8 \mathrm{~g} / \mathrm{dL}$ and $33.4 \%$. His white blood cell (WBC) count was $8.7 \mathrm{~K} / \mu \mathrm{L}$, and the platelet count was $146 \mathrm{~K} / \mu \mathrm{L}$. His lactate dehydrogenase $(\mathrm{LDH})$ was elevated to $368 \mathrm{U} / \mathrm{L}$, total bilirubin to 2.2 with indirect bilirubin of 2.0 , a reticulocyte number of $<10 \mathrm{~K} / \mu \mathrm{L}$, and a haptoglobin of $<7.75 \mathrm{mg} / \mathrm{dL}$. He had a B12 of $474 \mathrm{pg} / \mathrm{mL}$ and serum folate of $13.6 \mathrm{ng} / \mathrm{mL}$. Iron panel showed a low serum iron $284 \mu \mathrm{g} / \mathrm{dL}$, normal total iron binding capacity (TIBC) $320 \mu \mathrm{g} / \mathrm{dL}$, high iron saturation $89 \%$, and normal serum ferritin $122.6 \mathrm{ng} / \mathrm{mL}$. The peripheral blood smear showed spherocyte (Figure 1). Chest x-ray showed small left lower lobe pneumonia. 


\section{Cureus}

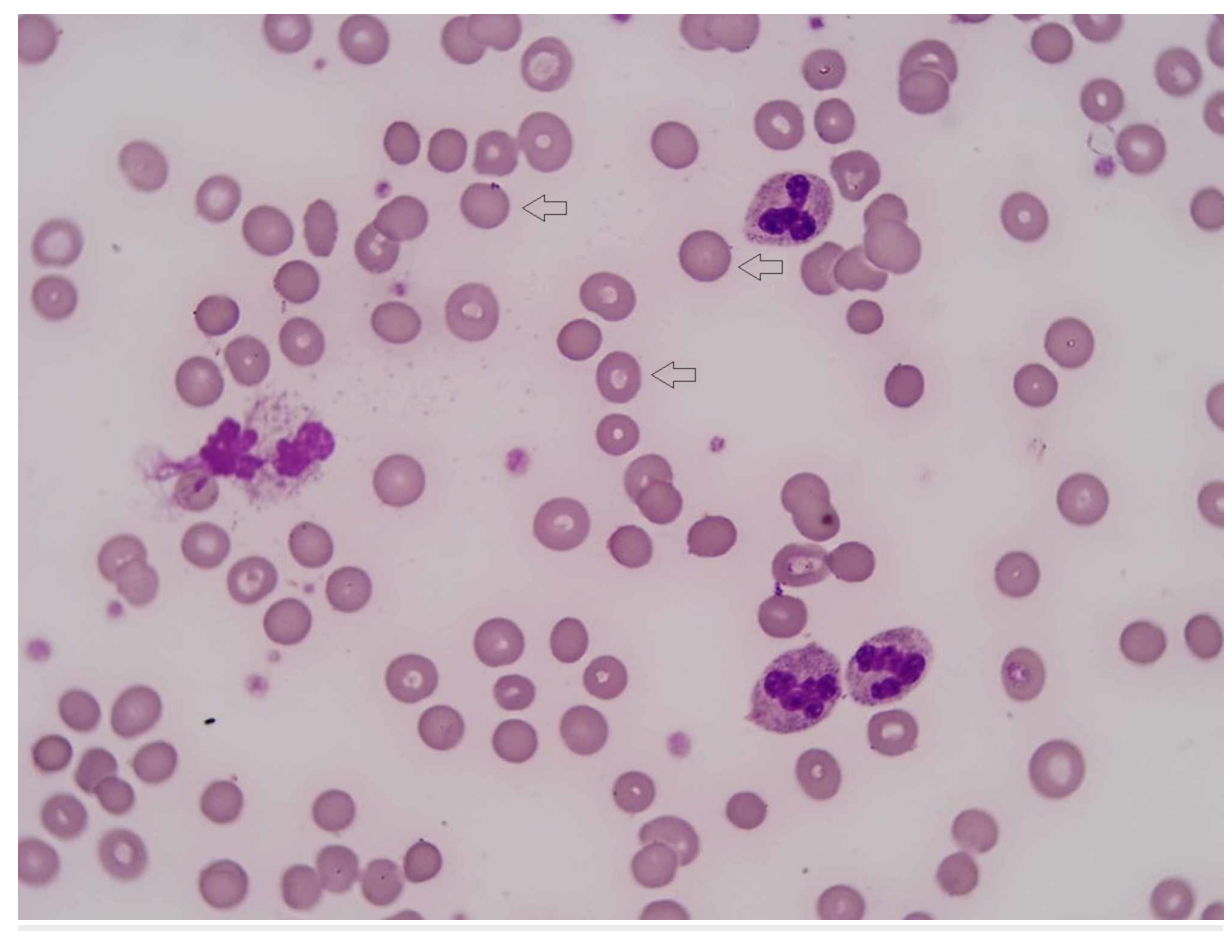

FIGURE 1: Peripheral blood smear showing spherocytosis (red arrows)

Red arrows: spherocytes in the patient's peripheral smear showing dense staining and small rounded appearance

Ultrasound revealed moderate splenomegaly (measuring $17.5 \mathrm{~cm} \times 6 \mathrm{~cm} \times 5 \mathrm{~cm}$ ), and coarse echotexture of the hepatic parenchyma secondary to fatty infiltration (Figure 2). CT of the head was normal, and a CT of the maxillary sinuses showed mild sinusitis in the maxillary sinuses. The patient was transfused four units of blood and was given IV antibiotics. He was later found to be positive for parvovirus DNA by PCR and Epstein-Barr virus (EBV) IgG and IgM. An osmotic fragility test was positive, confirming the diagnosis of hereditary spherocytosis. He tested negative for cold agglutinin, direct antiglobulin, serum protein electrophoresis, and urine hemosiderin. The patient's condition improved over time with supportive care and close monitoring. On follow-up, his hemoglobin improved to $10 \mathrm{~g} / \mathrm{dL}$, hematocrit to $33.6 \%$, reticulocyte count increased to $261.9 \mathrm{~K} / \mu \mathrm{L}, \mathrm{LDH} 158 \mathrm{U} / \mathrm{L}$, and a haptoglobin $<7.75 \mathrm{mg} / \mathrm{dL}$. 


\section{Cureus}

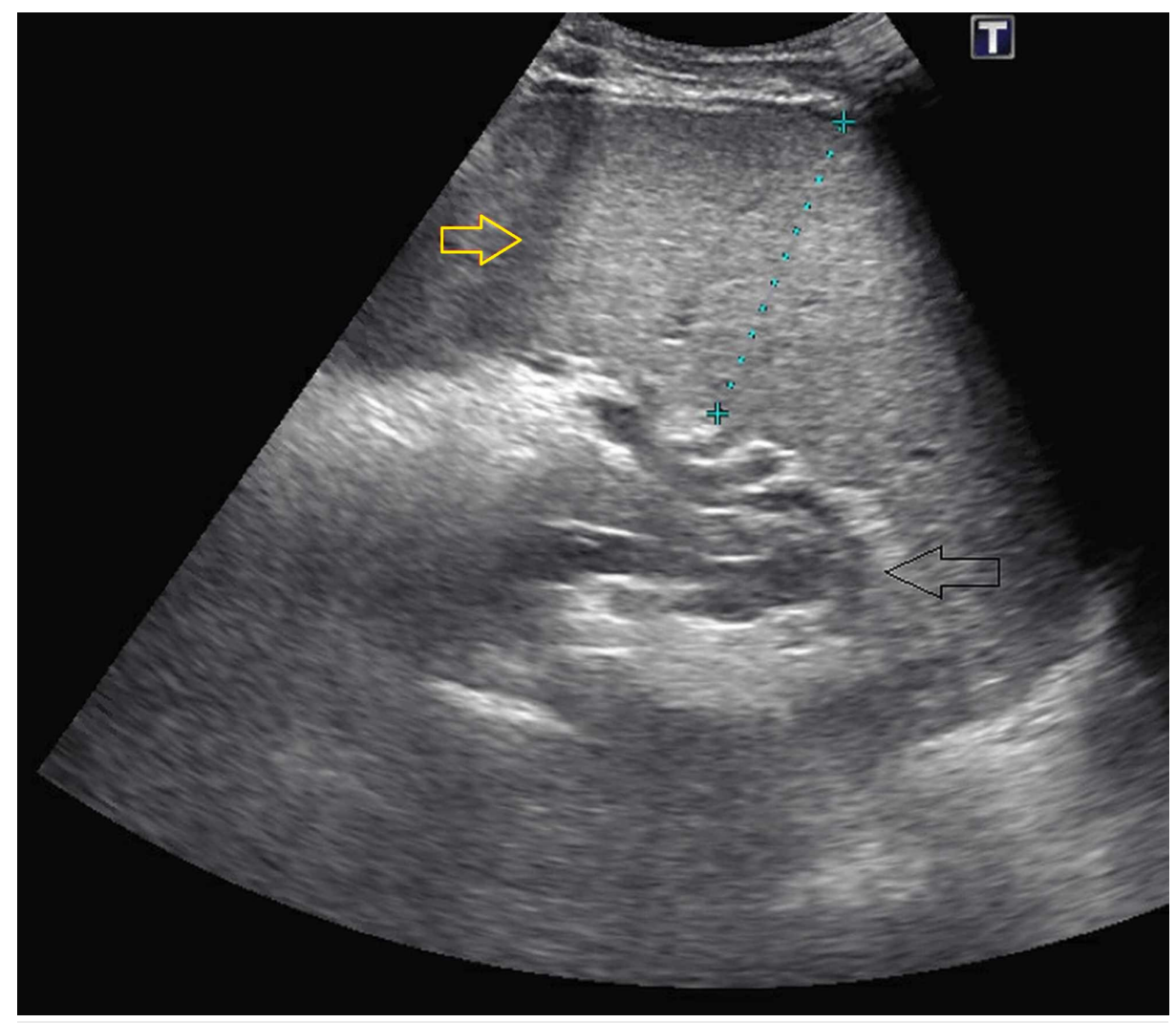

\section{FIGURE 2: Patient's right upper quadrant ultrasound showing}

splenomegaly (yellow arrow)

Yellow arrow: enlarged spleen; black arrow: stomach

\section{Discussion}

Human parvovirus is a non-enveloped single-stranded DNA virus from the Parvoviridae family and is the only member known to be pathogenic to humans. The virus is transmitted by respiratory droplets and seen commonly in children. It causes erythema infectiosum in immunocompetent children but can manifest as pure red cell aplasia in the immunocompromised [1]. Through the blood group P antigen receptor, it infects and destroys the erythroid progenitor cells inhibiting erythropoiesis, leading to acute erythroblastopenia and reticulocytopenia $[2,3]$. TAC is generally seen in older individuals, and the most common presentation is fever, lethargy, and non-specific flu-like symptoms. A significant drop in hemoglobin and hematocrit can be observed, particularly in patients with hereditary spherocytosis, sickle cell, and other structural abnormalities of the RBC. The anemia can be drastic, requiring urgent blood transfusions. A bone marrow biopsy would show severe red cell aplasia and giant pronromoblast with viral inclusions. Although TAC affects the erythroid cell lines, WBCs and platelets may also decline [4]. There are only a few documented cases with parvovirus and EBV coinfection, and the latter is most likely responsible for the splenomegaly observed in our patient. The specific role of coinfection on the severity of the aplastic crisis remains unclear [5]. TAC is a relatively self-limited infection that usually resolves in one to two weeks and confers a lasting immunity in immunocompetent individuals [4]. Immunocompromised patients are potentially at risk for reinfection and require treatment with intravenous immunoglobulin (IVIG) [6]. In general, most patients recover with supportive care and timely blood transfusions.

\section{Conclusions}

TAC is a rare and life-threatening condition associated with parvovirus infection. This condition is particularly worrisome for patients with disorders of RBC morphology, such as hereditary spherocytosis. The presentation can be non-specific, as seen in our patient, with a family history of hereditary spherocytosis, presented after a syncopal episode. He was appropriately managed with supportive care, and timely blood transfusions are required. It is vital to consider TAC in parents and professions that involve child care. If missed, TAC can have dire consequences.

\section{Additional Information}

\section{Disclosures}




\section{Cureus}

Human subjects: Consent was obtained by all participants in this study. Conflicts of interest: In compliance with the ICMJE uniform disclosure form, all authors declare the following: Payment/services info: All authors have declared that no financial support was received from any organization for the submitted work. Financial relationships: All authors have declared that they have no financial relationships at present or within the previous three years with any organizations that might have an interest in the submitted work. Other relationships: All authors have declared that there are no other relationships or activities that could appear to have influenced the submitted work.

\section{References}

1. Heegaard ED, Brown KE: Human parvovirus B19. Clin Microbiol Rev. 2002, 15:485-505.

10.1128/cmr.15.3.485-505.2002

2. Kobayashi Y, Hatta Y, Ishiwatari Y, Kanno H, Takei M: Human parvovirus B19-induced aplastic crisis in an adult patient with hereditary spherocytosis: a case report and review of the literature. BMC Res Notes. 2014, 7:1-5. 10.1186/1756-0500-7-137

3. Cefalo MG, Arlotta A, Maurizi P: Human parvovirus B19 and Epstein-Barr virus co-infection in a child with hereditary spherocytosis. Eur Rev Med Pharmacol Sci. 2012, 16:265-269.

4. Eid AJ, Ardura MI: Human parvovirus B19 in solid organ transplantation: guidelines from the American society of transplantation infectious diseases community of practice. Clin Transplant. 2019, 33:e13535. 10.1111/ctr. 13535

5. Gallinella G: Molecular testing for parvoviruses. Diagnostic Molecular Pathology. Coleman W, Tsongalis G (ed): Academic Press, San Diego; 2017. 103-113. 10.1016/b978-0-12-800886-7.00009-1

6. Young NS, Brown KE: Parvovirus B19. N Engl J Med. 2004, 350:586-597. 10.1056/NEJMra030840 